\title{
PELAKSANAAN WEWENANG WAKIL PRESIDEN N DALAM PENYELENGGARAAN PEMERINTAHAN
}

OLEH :

\author{
BAMBANG HERMAWAN \\ MAHASISWA FAKULTAS HUKUM UNIVERSITAS AIRLANGGA
}

\begin{abstract}
ABSTRAK
No details the authority owned by the Vice President could potentially lead to legal uncertainty. Whereas in the construction of the position incumbent of the position of the Vice President has a position that is very fundamental research purposes in writing this is to know the authority of the Vice President in the Organization of the Government and To knowing the implementation authority Vice President in organizing the Government. In this study the normative legal research using methods based on relevant legislation and other legal materials related to the substance of the research, then connected with problems in This research. Research results show that the authority of the Vice President is not set explicitly in the legislation. Authority of the Vice President are only found by analyzing the legislation. ' Where there are 3 Vice Presidential Authority: the authority of the Vice President as the representative of the President, the powers of the Vice President As President, the Maid Authority of the Vice President as successor to the President whereas the implementation authority Vice President subject to the authority of the source. Source from authority of the attribution of the implementation authority Vice President gained the authority directly by the 1945 Constitution and its implementation without going through intermediaries. For the delegation of authority then the implementation authority in advance must there is a delegation of authority that has the force of law so that the execution of the authority of the Vice-president can be strengthened by positive law in order to set up and defend it.
\end{abstract}

Keywords: Authority, Vice President, Government

\section{A. PENDAHULUAN}

Negara Indonesia merupakan Negara Hukum sebagaimana di sebutkan dalam Pasal 1 ayat (3) Undang Undang Dasar 1945 bahwa "Negara Indonesia adalah negara hukum". Penguatan atas Negara hukum juga dinyatakan dalam Pasal 1 ayat (2) yang dinyatakan bahwa, "kedaulatan berada di tangan rakyat dan dilaksanakan menurut Undang-Undang Dasar”. Hal inilah yang kemudian memberikan pengakuan bahwa dianutnya prinsip supremasi hukum dan konstitusi di Indonesia. Selain itu berdasarkan pasal tersebut, Indonesia juga menganut prinsip demokrasi, sehingga dalam praktik ketatanegaraan Indonesia prinsip demokrasi dan Negara hukum dijalankan secara bersama-sama. 
Salah satu wujud dari penegakan demokra konstitusional adalah adanya pemilihan umum yang didasarkan undang-undang. Pemilihan umum di Indonesia diselenggarakan untuk memilih anggota Dewan Perwakilan Rakyat, anggota Dewan Perwakilan Daerah, Presiden dan Wakil Presiden, dan Dewan Perwakilan Rakyat Daerah.

Berkenaan dengan hal tersebut, Presiden dan Wakil Presiden merupakan jabatan yang dipilih secara langsung oleh rakyat dikarenakan presiden memegang kekuasaan eksekutif. Presiden Republik Indonesia menurut Pasal 4 ayat (1) Undang Undang Dasar 1945 memegang kekuasaan pemerintahan negara menurut undang-undang dasar. Inilah yang disebut sebagai prinsip "constitutional government" (Jimly Asshiddiqie, 2008:, Hlm 327-328).

Makna pemilihan presiden dan wakil presiden dipilih dalam satu pasangan secara langsung oleh rakyat menggambarkan jabatan presiden dan wakil presiden adalah satu kesatuan pasangan dan merupakan satu kesatuan lembaga kepresidenan. Dengan kata lain, keduanya merupakan dwi-tunggal. Meskipun keduanya merupakan satu kesatuan intitusi kepresidenan, keduanya adalah dua jabatan konstitusional yang berbeda. Karena itu, dapat diparadigmakan jabatan presiden dan wakil presiden merupakan dua organ yang tak terpisahkan tetapi dapat dan harus dibedakan satu sama lain.(Jimly Ashshiddiqie, 2006: hlm 129).

Dalam menjalankan tugasnya, presiden dibantu oleh seorang wakil presiden. Hal tersebut dirumuskan dalam Pasal 4 ayat (2) Undang Undang Dasar 1945, yaitu "Dalam melakukan kewajibannya, Presiden dibantu oleh satu orang Wakil Presiden".Jika dikaji pasal 17 ayat (1) Undang Undang Dasar 1945, juga ditentukan bahwaPresiden dibantu oleh menteri-menteri NegaraDalam pasal 4 ayat (2) dan Pasal 17 ayat (1) sama-sama memakai istilah "dibantu”. Jika demikian berarti menurut Undang Undang Dasar 1945, wakil presiden dan para menteri Negara sama-sama merupakan pembantu presiden. Padahal menteri Negara menurut Pasal 17 ayat (2) diangkat dan diberhentikan oleh Presiden, sedangkan presiden dan wakil Presiden menurut Pasal 6A ayat (1) samasama dipilih dalam satu pasangan secara langsung oleh rakyat.(Jimly Ashshiddiqie, 2008: hlm 328) Hal ini jelas mempunyai konsekuensi yang berbeda.

Politik hukum pengisian jabatan wakil presiden yang disatukan dengan mekanisme pengisian jabatan presiden merupakan hal yang sangat prinsipil. Kemudian 
mengenai kedudukan dan kewenangan wakil presiden dalam Negara yang menganut paham demokrasi konstitusional merupakan hal yang sangat fundamental.

Prinsip negara hukum menganalogikan setiap kewenangan dalam jabatan negara haruslah ditentukan melalui peraturan perundang-undangan sehingga menghindarkan dari praktik negara kekuasaan, termasuk kedudukan wakil presiden.Menurut Jimly Ashsiddiqie, wakil presiden mempunyai lima kemungkinan posisi terhadap presiden, yaitu: (Jimly Ashshiddiqie, 2006: hlm 130).

Tidak jelasanya kewenangan yang dimiliki oleh wakil presiden berpotensi mengakibatkan ketidakpastian hukum. Padahal dalam konstruksi kedudukan jabatan pemerintahan kedudukan wakil presiden memiliki kedudukan yang sangat fundamental. Jika dikaji praktik pemerintah hasil pemilu presiden dan wakil presiden pasca amandemen Undang Undang Dasar 1945, yakni periode pemerintahan Susilo Bambang Yudhoyono-Jusuf Kalla, Susilo Bambang Yudhoyono-Boediono dan Joko Widodo-Jusuf Kalla belum memiliki landasan yuridis yang pasti mengenai apa saja yang menjadi kewenangan seorang wakil presiden dalam masa periode tertentu. Hal tersebut memiliki dampak negatif dikarenakan potensi penyalahgunaan kekuasaan oleh seorang wakil presiden. Kemudian penguatan prinsip Negara hukum juga akan terhambat

Dari uraian latar belakang masalah di atas maka Masalah yang diangkat dalam penelitian ini adalah Bagaimana wewenang wakil presiden dalam penyelenggaraan pemerintahan dan Bagaimanakah pelaksanaan wewenang wakil presiden dalam penyelenggaraan pemerintahan.

Adapun tujuan penelitian dalam tulisan ini adalah Untuk mengetahui wewenang wakil presiden dalam penyelenggaraan pemerintahan dan Untuk mengetahui pelaksanaan wewenang wakil presiden dalam penyelenggaraan pemerintahan.

\section{B. METODE PENELITIAN}

Dalam penelitian ini penulis menggunakan metode penelitian hukum normatif yang mengacu pada peraturan perundang-undangan yang relevan dan bahan hukum lain yang berhubungan dengan substansi penelitian, kemudian dihubungkan dengan pokok permasalahan dalam penelitian ini. Pendekatan yang dilakukan dalam penelitian ini adalah pendeka perundang-undangan (statute aprroach), pendekatan konseptual 
(conseptual aprroach), pendekatan kasus (case aprroach) dan pendekatan komparatif (comparative aprroach)(Peter Mahmud Marzuki, 2015: hlm 133).

Jenis bahan hukum dalam penelitian ini menggunakan dua jenis bahan hukum, yaitu bahan hukum primer dan bahan hukum sekunder. Bahan hukum primer yaitu data yang terdiri dari peraturan perundang-undangan, catatan-catatan resmi atau risalah sidang pembentukan peraturan perundang-undangan, Bahan hukum sekunder yaitu merupakan data yang di peroleh melalui wawancara yang di lakukan langsung dengan responden yang dapat mewakili beberapa sumber dalam hal ini adalah staf humas sekretariat Wakil Presiden dan beberapa pakar hukum. Serta publikasi tentang bahan hukum yang bukan merupakan catatan resmi. Publikasi tersebut meliputi bukubuku teks, kamus hukum, jurnal-jurnal hukum dan makalah hukum.

Teknik Pengumpulan bahan hukum dalam penelitian ini ditempuh prosedur.Studi kepustakaan (Library Research)Studi kepustakaan adalah mengumpulkan data yang dilakukan dengan cara membaca, mengutip, mencatat dan memahami berbagai literatur yang berkaitan dengan permasalahan yang diteliti (Zainuddin Ali, 2011: hlm 176).

\section{HASIL DAN PEMBAHASAN}

\section{Wewenang Wakil Presiden dalam Penyelenggaraan Pemerintahan}

Wewenang dalam Undang-Undang No 30 tahun 2014 tentang Administrasi Pemerintahan dalam Pasal 1 ayat 5 diatur bahwa "Wewenang adalah hak yang dimiliki oleh Badan dan/atau Pejabat Pemerintahan atau Penyelenggara negara lainnya untuk mengambil keputusan dan/atau tindakan dalam penyelenggaran pemerintahan"(UU No 30 Tahun 2014 Tentang administrasi Pemerintahan). Dimana sumber wewenang secara teoritik, kewenangan yang bersumber dari peraturan perundang undangan diperoleh melalui tiga cara yaitu atribusi, delegasi, dan mandat (Ridwan HR, 2013: hlm 101).

Mengenai atribusi, delegasi dan mandat ini penjelasannya sebagaimana telah dibahas sebelumnya dalam tinjauan pustaka sebagaimana dalam Undang-Undang Nomor 30 Tahun 2014 tentang Administrasi Pemeerintahan sebagai berikut:

a. Atribusi adalah pemberian kewenangan kepada Badan/atau Pejabat Pemerintahan oleh Undang-Undang Dasar Negara Republik Indonesia Tahun 1945 atau Undangundang. 
b. Delegasi adalah pelimpahan Kewenangan dari Badan dan/atau Pejabat Pemerintahan yang lebih tinggi kepada Badan dan/atau Pejabat Pemerintahan yang lebih rendah dengan tanggung jawab dan tanggung gugat beralih sepenuhnya kepada penerima delegasi.

c. Mandat adalah pelimpahan Kewenangan dari Badan dan/atau Pejabat Pemerintahan yang lebih rendah dengan tanggungjawab dan tanggung gugat tetap berada pada pemberi mandat. (UU No 30 Tahun 2014 Tentang Administrasi Pemerintahan)

Dari ketiga cara memperoleh kewenangan di atas, untuk kewenangan Wakil Presiden dalam sistem ketatanegaraan Indonesia, tidak ada aturan khusus yang membahas mengenai wewenangnya. Pengaturan terkait Wewenang wakil presiden hanya diatur dalam Undang-Undang Dasar 1945 dalam pasal 4 ayat 2 yang diatur bahwa "Dalam melakukan Kewajibannya Presiden dibantu oleh satu orang Wakil Presiden". Terhadap hal ini tidak ada ukuran pasti terkait ukuran pembantuan Wakil Presiden kepada Presiden. pendekatan terkait ukuran Pemabantuan Wakil Presiden hanya dapat dilakukan dengan menafsirkan kalimat pasal 4 ayat 2 Undang-Undang Dasar 1945. Dimana secara leksiografi, kata "dibantu" berasal dari kerta kerja "bantu" yang dapat diartikan sebagai tolong, dari kata kerja "bantu" tersbut muncul kata kerja "membantu" yang berarti memberi sokongan (tenaga dan sebagainya) supaya kuat (kukuh, berhasil baik dan sebagainya) (Kamus Besar Bahasa Indonesia, 1999: hlm 91). Sepadan dengan kata kerja menolong yang berarti 1. Membantu untuk meringankan beban (penderitaan, kesukaran dan sebagainya); 2. Membantu supaya dapat melakukan sesuatu; 3. Melepaskan diri dari (bahaya, bencana dan sebagainya); 4. Dapat meringankan (penderitaan dan sebagainya) (Kamus Besar Bahasa Indonesia, 1996: hlm 96).

Yang dimaksud "wakil" adalah kata benda yang berarti 1. Orang yang dikuasakan menggantikan orang; 2. Orang yang dipilih sebagai utusan negara; duta; 3. Orang yang menguruskan perdagangan dan sebagainya untuk orang lain; 4. Jabatan yang kedua setelah yang tersebut didepannya(Kamus Besar Bahasa Indonesia, 1996: hlm 1123). Beranjak dari beberapa arti wakil tersebut, dapat disimpulkan bahwa Wakil Presiden sama dengan orang yang dikuasakan menggantikan Presiden dalam kondisis tertentu atau jabatan kedua setelah jabatan Presiden. 
Dalam kamus Hukum, kata "wakil” diartikan sebagai pengganti atau orang kedua yang dapat mengambil keputusan, (Andi Hamzah, 1986: hlm 627) sedangkan berdasarkan istilah yang digunakan dalam Pasal 4 ayat 2 Undang-Undang Dasar 1945 tersebut, yakni kata "dibantu" menunjuk pada kalimat pasif sehingga dapat dipahami bahwa Presiden (secara pasif) dibantu oleh Wakil Presiden dalam melakukan kewajibannya. Oleh karna itu, Presiden wajib meminta bantuan Wakil Presiden dalam melaksanakan kewajibannya sedangkan Wakil Presiden berkewajiban membantu Presiden.

Mengacu pada penafsiran leksiografis-terminologis tersebut, dapat disimpulkan bahwa :

1. Kata kerja "dibantu" berpadanan dengan kata kerja "ditolong", selanjutnya.

2. Sifat dan bantuan Wakil Presiden tersebut adalah aktif dalam pelaksanaan kewajiban Presiden. Artinya Wakil Presiden wajib memberikan bantuannya demi terselenggaranya pelaksanaan tugas yang diemban Presiden (dalam hal ini penyelenggaraan pemerintahan negara)

3. Bentuk pembantuan dalam arti menolong; meringankan kewajiban Presiden, agar pelaksanaan kewajibannya berhasil dengan baik.(Mochammad Isnaeni Ramdhan, 2015: hlm 79).

Selain hal di atas sebagaimana disebutkan dalam pembahasan tinjauan pustaka bahwa Wakil Presiden sebagai pembantu presiden dapat memilliki 4 kemungkinan posisi yakni.

\section{a. Kewenangan Wakil Presiden Sebagai Wakil Dari Presiden.}

Wakil presiden adalah sebagai pejabat yang dapat bertindak sebagai wakil dari presiden yaitu mewakili presiden dalam melaksanakan tugas dan kewajiban serta wewenang jabatan presiden terlebih dahulu harus terdapat hal-hal yang menyebabkan presiden berhalangan melaksanakan tugas, kewajiban dan wewenang jabatannya dan sifat dari berhalangan tersebut adalah sementara. Secara teoritis, yang menyebabkan presiden berhalangan sementara seperti (Harun Alrasyid, 1999: hlm 66): Sakit, Berkunjung, Kedaerah, Berkunjung ke luar negeri, Cuti (istrahat), Sibuk (pada acara) dan lain-lain. Sebagai pejabat yang mewakili Presiden dalam melaksanakan tugas dan wewenang jabatan presiden, Wakil Presiden terlebih dahulu harus mendapat perintah atau diberi kuasa oleh Presiden, tampa adanya kuasa atau perintah dari Presiden, Wakil 
Presiden tidak dapat mewakili presiden dalam melaksanakan tugas dan wewenang jabatan Presiden. Adanya perintah atau kuasa dari presiden kepada Wakil Presiden merupakan suatu mandat. Presiden sebagai pemberi mandat dan Wakil Presiden sebagai penerima mandat. Sebagai pemberi mandat, Presiden kapan saja dapat menarik mandatnya dari Wakil Presiden sesuai aturan yang berlaku. Wakil Presiden sebagi penerima mandat harus menjalankan mandat tersebut sesuai dengan isi dan maksud mandat yang diberikan.

\section{b. Kewenangan Wakil Presiden Sebagai Pembantu Presiden.}

Untuk mengetahui apa saja yang menjadi wewenang Wakil Presiden sebagai pembantu Presiden, terlebih dahulu harus diketahui apa saja yang menjadi kewajiban dari Presiden, hal ini sebagai dasar kewenangan Wakil Presiden sebagai pembantu Presiden. Salah satu wewenang Presiden diatur dalam Pasal 4 ayat (1) yakni: Presiden Republik Indonesia memegang kekuasaan pemerintahan menurut Undang-Undang Dasar, dan Pasal (2) UUD NRI Tahun 1945 yakni dalam melakukan kewajibannya Presiden dibantu oleh satu orang Wakil Presiden. dimana apabila ayat kedua tersebut dihubungkan dengan ayat pertama, maka hal ini berarti bahwa Wakil Presiden memberi bantuan kepada Presiden dalam bidang kekeuasaan pemerintahan (eksekutif).(Sri Soemantri, 1993: hlm 116).Dengan demikian, bentuk bantuan Wakil Presiden kepada Presiden adalah bantuan dalam hal melaksanakan Undang-Undang. Hal ini juga bersesuaian dengan sumpah/janji presiden dan/atau wakil presiden yang ditentukan dalam Pasal 9 ayat (1) UUD NRI Tahun 1945 yakni:

Sebelum memangku jabatannya, Presiden dan Wakil Presiden bersumpah menurut agama, atau berjanji dengan sungguh-sungguh di hadapan Majelis Permusyawaratan Rakyat atau Dewan Perwakilan Rakyat sebagai berikut :

Sumpah Presiden (Wakil Presiden) : Demi Allah, saya bersumpah akan memenuhi kewajiban Presiden Republik Indonesia (Wakil Presiden Republik Indonesia) dengan sebaik-baiknya dan seadiladilnya, memegang teguh Undang-undang Dasar dan menjalankan segala undang-undang dan peraturannya dengan seluruslurusnya serta berbakti kepada Nusa dan Bangsa. Janji Presiden (Wakil Presiden) : Saya berjanji dengan sungguh-sungguh akan memenuhi kewajiban Presiden Republik Indonesia (Wakil Presiden Republik Indonesia) dengan sebaik-baiknya dan seadilnya, 
memegang teguh Undang-undang Dasar dan menjalankan segala undang-undang dan peraturannya dengan selurus-lurusnya serta berbakti kepada Nusa dan Bangsa.

\section{c. Kewenangan Wakil Presiden Sebagai Pengganti Presiden.}

Sebagai pengganti Presiden, seorang Wakil Presiden tidak lagi disebut Wakil Presiden, melainkan sebagai Presiden, dan juga tidak terjadi rangkap jabatan. Artinya adalah dengan mengganti kedudukan Presiden yang lowong, Wakil Presiden terlepas dari jabatan sebagai Wakil Presiden. Sebagai contohnya jika Presiden meninggal dunia, meka secara langsung Wakil Presiden akan menggantikannya sebagai Presiden. Karena sebagai presiden maka segala kewenangan yang ada pada jabatan Presiden adalah menjadi kewenangan presiden pengganti (yang sebelumnya wakil presiden).

Dari hal di atas dapat disimpulkan bahwa wewenang Wakil Presiden yakni berupa:

1. Wewenang yang bersumber atribusi yakni:

Wewenang wakil presiden sebagai pembantu presiden dan Wakil presiden sebagai pengganti presiden, sebagaimana yang telah dijelaskan dalam undang-undang No 30 Tahun 2014 tentang administrasi pemerintahan bahwa atribusi adalah pemberian kewenagan kepada badan dan/atau pejabat pemerintahan oleh Undangundang Dasar Negara Republik Indonesia Tahun 1945 atau undang-undang. Berangkat dari hal tersebut, dalam pasal 2 Undang-Undang Dasae Negara Republik Indonesia Tahun 1945 yakni dalam melakukan kewajibannya Presiden dibantu oleh satu orang Wakil Presiden.

2. Wewenang yang bersumber delegasi yakni:

Wakil presiden sebagai pengganti presiden, dalam menjalankan kewenangannya Wakil Presiden tidak memerlukan perintah atau persetujuan dari Presiden kecuali dikehendaki lain oleh Presiden atau peraturan perundang-undangan. Pola hubungan presiden dan wakilnya pasca orde baru dan reformasi, mengalami pergeseran sehingga tugas dan wewenang Wakil Presiden tergantung pada pembagian tugas antara keduanya, dan pembagian itu tetap merupakan beleid atau kebijakan (policy) Presiden kepada Wakil Presiden.

3. Wewenang yang bersumber mandat yakni:

Wewenang wakil presiden sebagai wakil dari presiden, mewakili presiden dalam melaksanakan tugas dan kewajiban serta wewenang jabatan presiden terlebih dahulu harus terdapat hal-hal yang menyebabkan presiden berhalangan melaksanakan tugas, 
kewajiban dan wewenangjabatannya dan sifat dari berhalangan tersebut adalah sementara. Sebagai pejabat yang mewakili Presiden dalam melaksanakan tugas dan wewenang jabatan presiden, Wakil Presiden terlebih dahulu harus mendapat perintah atau diberi kuasa oleh Presiden, tampa adanya kuasa atau perintah dari Presiden, Wakil Presiden tidak dapat mewakili presiden dalam melaksanakan tugas dan wewenang jabatan Presiden. Adanya perintah atau kuasa dari presiden kepada Wakil Presiden merupakan suatu mandate.

\section{Pelaksanaan Wewenang Wakil Presiden Dalam Penyelenggaraan Pemerintahan.}

Pelaksanaan adalah suatu tindakan atau pelaksanaan dari sebuah rencana yang sudah disusun secara matang dan terperinci, implementasi biasanya dilakukan setelah perencanaan sudah dianggap siap. Secara sederhana pelaksanaan bisa diartikan penerapan. Pelaksaan menurut kamus besar bahasa indonesia diartikan sebagai perbuatan melaksanakan.

Majone dan Wildavsky mengemukakan pelaksanaan sebagai evaluasi. Browne dan Wildavsky mengemukakan bahwa Pelaksanaan adalah perluasan aktivitas yang saling menyesuaikan. (Nurdin Usman, 2002: hlm 70).Pengertian-pengertian di atas memperlihatkan bahwa kata pelaksanaan bermuara pada aktivitas, adanya aksi, tindakan, atau mekanisme suatu sistem. Ungkapan mekanisme mengandung arti bahwa pelaksanaan bukan sekedar aktivitas, tetapi suatu kegiatan yang terencana dan dilakukan secara sungguh-sungguh berdasarkan norma tertentu untuk mencapai tujuan kegiatan.

\section{PENUTUP}

Adapun kesimpulan dari uraian pada pembahasan yang telah di jelaskan pada bab sebelumnya adalah sebgai berikut:

1. Kewenangan Wakil Presiden tidak diatur secara tegas dalam peraturan perundangundangan. Wewenang Wakil Presiden hanya ditemukan dengan menganalisis peraturan perundang-undangan.`Dimana ada 3 Kewenangan Wakil Presiden yakni: Kewenangan Wakil Presiden Sebagai Wakil Dari Presiden, Kewenangan Wakil Presiden Sebagai Pembantu Presiden, Kewenangan Wakil Presiden Sebagai Pengganti Presiden

2. Pelaksanaan kewenangan wakil presiden tergantung sumber dari kewenangan tersebut. Kewenangan yang berumber dari atribusi pelaksanaan wewenang Wakil 
Presiden memperoleh wewenang secara langsung oleh Undang-Undang Dasar 1945 dan pelaksanaannya tanpa melalui perantara. Untuk kewenangan yang bersumber dari delegasi maka pelaksanaan wewenang ini terlebih dahulu haarus ada pendelegasian wewenang yang memiliki kekuatan hukum sehingga pelaksanaan wewenang Wakil Presiden dapat dikuatkan oleh hukum positif guna mengatur dan mempertahankannya.

\section{DAFTAR PUSTAKA}

Alrasid.Harun. 1993.Masalah Pengisian Jabatan Presiden.Disertasi. Program Pascasarjana. Universitas Indonesia.

Asshiddiqie, Jimly.1986.Pergumulan Peran Pemerintah dan Parlemen dalam Sejarah (telaah perbandingan konstitusi berbagai negara), UI-PRESS: Jakarta. . 2004.Format Kelembagaan Negara dan Pergeseran Kekuasaan dalam UUD 1945, FH UII: Yogyakarta.

. 2006.Konstitusi dan Konstitusionalisme, Sekjen \& Kepanitraan Mahkama Konstitusi RI: Jakarta. . 2006.Perkembangan dan Konsolidasi Lembaga Negara, Sekjen \& Kepanitraan Mahkama Konstitusi RI: Jakarta. . 2008.Pokok-pokok Hukum Tata Negara, Bhuana Ilmu Populer: Jakarta.

Ali, Zainuddin. 2011. Metode Penelitian Hukum. Sinar Grafika: Jakarta.

Basah. Sjcharan. 1992.Perlindungan Hukum Atas Sikap Tindakan Administrasi Negara, Alumni: Bandung.

Budiardjo. Miriam. 2008.Dasar-Dasar Ilmu Politik, Gramedia: Jakarta.

Hamzah. Andi. 1986.Kamus Hukum.Ghalia Indonesia: Jakarta

HR. Ridwan. 2013.Hukum Administrasi Negara, PT Raja Grafindo Persada: Jakarta.

Hamidi. Jazim. 2009.Teori Politik Hukum Tata Negara, Alumni:Bandung.

Huda. Ni'MAtul. 2009.Lembaga Negara Masa Transisi Menuju Demokrasi, UII PRess:Yogyakarta.

Librayanto. Romi. 2009.Ilmu Negara, Pustaka Refleksi: Makassar.

Manan, Bagir. 1987. Peranan Peraturan perundang - undangan dalam Pembinaan Hukum Nasional. Amico: Bandung. 2003. Lembaga Kepresidenan. FH UII Press: Yogyakarta. 
Marbun. SF. 1997.Peradilan Administrasi Negara dan Upaya Administratif di Indonesia, Liberty: Yogyakarta.

Marzuki. Peter Mahmud. 2015.Penelitian Hukum, Prenada Media group: Jakarta.

Ruslan, Achmad. 2013.Teori dan Panduan Praktik Pembentukan Peraturan Perundang Undangan Di Indonesia.Mahakarya Rangkang Offset Yogyakarta: Yogyakarta.

Ramdhan. Mochamad Isnaeni. 2015.Jabatan Wakil Presiden Menurut Hukum Tata Negara Indonesia, Sinar Grafika: Jakarta.

Sunarjati Hartono. C.F.G. 1976.Apakah The Rule of Law, Alumni:Bandung.

Soemantri. Sri. 1993.Tentang Lembaga-lembaga Negara Menurut UUD 1945, Aditya Bandung:Bandung.

Thalib. Abdul Rasyid. 2006.Wewenang Mahkama Konstitusi dan Aplikasinya dalam Sistem Ketatanegaraan Republik Indonesia, Citra Aditya Bakti:Bandung.

Tahir Azhary. Muh. 2003.Negara Hukum Suatu Study Tentang Prinsip-Prinsipnya Dilihat dari Segi Hukum Islam, Implementasinya Pada Periode Negara Medina dan Masa Kinii, Permada Media:Jakarta. 